\title{
原料品質変化にともなうピッチ処理について
}

栗田工業株式会社 技術部開発課 ○和田 敏, 陳 嘉義, 駿河圭二

\section{Pitch Control with Pulp Quality Change}

OSatoshi Wada, Chen Jiayi and Keiji Suruga

Paper Chemicals Section, Kurita Water Industries Ltd.

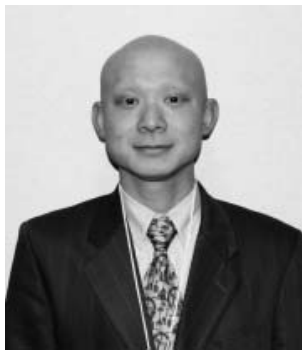

和田 敏

\begin{abstract}
Recently, papermaking industry has executed waste paper recycling actively from the situation of global environment maintenance and resources protection. With this situation, pitch trouble has been increasing by increasing of the wastepaper usage rate, neutralization of papermaking $\mathrm{pH}$, reduction of papermaking machine using water, speedup of papermaking machine. Pitch trouble is one of important cause of paper machine run ability.

To reduce pitch trouble, various pitch control agent has been applying. And many pitch evaluation methods has been using. Each method has various features and is used depending on the situation and a purpose. We use evaluation method noting “Deposit potential”, and we are applying pitch control agents and fixing agents.

In this article, we collect concerning the basic item of the pitch and pitch control. And we introduce the example of application of the pitch control agent.
\end{abstract}

分類 : $\mathrm{W}_{11}$ ピッチコントロール剤, $\mathrm{R}_{5}$ 古紙パルプ

\section{1. はじめに}

近年, 紙パルプ業界では, 地球環境保全や資源保護の立 場から古紙のリサイクルを積極的に行っており，日本製紙 連合会では 2010 年の古紙利用率を $62 \%$ までに増加するこ とを目標としている。古紙利用率増加にともない, 背糊や ラテックスが付着した古紙の使用量が増加し，また，抄紙 $\mathrm{pH}$ の中性化や抄紙系内のクローズド化, マシンの高速化 なども相俟って, 抄紙系内に古紙由来のピッチ成分が増加 し，マシン用具污れや欠点トラブルなど抄造効率低下の原 因の一つとなっている ${ }^{1)}$ 。

ピッチコントロール剤は，この様なトラブルを軽減する ため用いられている。本報はピッチの基本的事項をまとめ ると共に, 弊社のピッチ評価方法とピッチコントロール剂 の紹介を行なう。

\section{2. 原料の変化}

古紙の回収率および利用率の推移を図 1 に示す。古紙の 利用率は紙向けの消費により増加している。一方回収率は
利用率以上に増加している。これは, 古紙の輸出量が増加 しているからであり, 特に中国向けの輸出が増加している2。 古紙の回収量が増加することで, 今まで使用されていな かった背糊やラベル紙など粘着性物質やコート紙が混入し た古紙も利用されるようになり，古紙の品質の低下が懸念 されている。

抄紙機の付着物や紙中異物の成分についても近年変化が

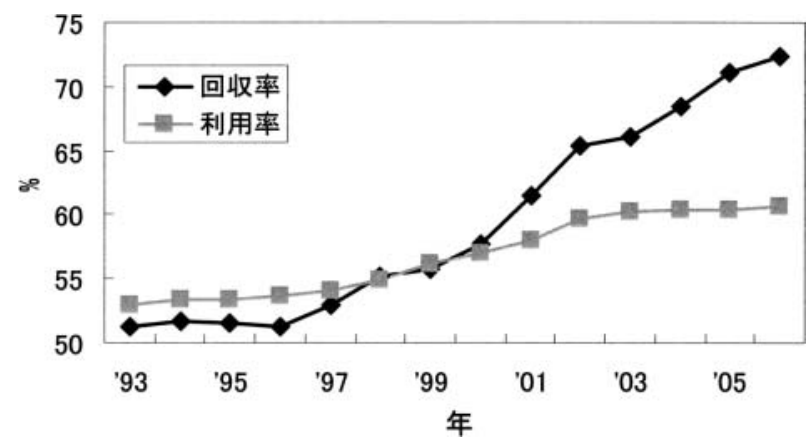

図 1 古紙回収率・利用率の推移 
見られ，板紙マシンにおいてポリアクリル酸エステル系の 障害が増えている。これはポリアクリル酸エステルを使用 した宅急便ラベルの混入増加に由来すると言われている ${ }^{3)}$ 。 また抄紙 $\mathrm{pH}$ の中性化も進んでおり，官庁出版物中の中 性紙の割合は，1988 年は 58.4\% であったが 2003 年には 92.3\% まで増加している ${ }^{4)}$ 。中性紙が古紙となって回収お よび利用されることにより，填料として配合されている炭 酸カルシウムに起因するスケールトラブルが発生すること が懸念される。さらに，中性抄造による硫酸バンド使用量 の減少は, 硫酸バンドによる系内のピッチの定着効果が低 減し，污れが残留することになる。

また，水の再利用や使用方法の見直しによって抄紙工程 のクローズド化が進んでいることで，水と共に系外へ排出 される污れの原因物質が減少し, 系内に濃縮することが推 察される。

これらのことから，抄紙系内では污れの原因物質の増加 や質の変化が起こっており, 従来以上の問題を生させるよ うになり，抄紙機の生産効率の低下が懸念される。

この対策として，スクリーン等の強化をはじめとした機 械的な発生源対策と, 薬品による化学的な対策が取られて いる。

\section{3. 製紙工程における污れの原因物質 ${ }^{155) 6}$}

上記のような様々な因子から，製紙工程には様々な污れ 物質が生成し付着する。これらは総称してデポジットと呼 ばれている。デポジットは，炭酸カルシウムなどスケール 物質の無機系デポジット，スライムなどの生物系デポジッ ト, 天然材木および古紙由来の有機系デポジットに区別さ れる。デポジットはこれらが共存した状態で存在している 場合がほとんどである。またその付着状況も，抄紙条件や 場所, 抄き出し後の日数によって異なり, 始めに有機系デ ポジットが付着した後，生物系および無機系デポジットが 付着する場合などもある。

有機系デポジットは「ピッチ」と「スティッキー」に分 類される。

ピッチとは，樹脂酸，脂肪酸，グリセライドなど木材に 由来する天然系粘着物である。また，スティッキーとは， 古紙から持ち込まれる EVA（エチレン酢酸ビニル）等の 接着剤や, 抄紙工程で添加されるサイズ剤などの内添薬品, 古紙または塗工工程の損紙から持ち込まれるカラー, など に由来する人工合成系粘着物をいう。実際の抄紙系ではこ
れらの粘着物が共存していることがほとんどであり厳密に 分別することは難しいため, 以後本稿では「ピッチ」と総 称する。図 2 に有機系デポジット（ピッチ）の分類を示す。

\section{4. ピッチ障害の発生 ${ }^{78}$}

パルプの洗浄工程を抜けた抄紙工程中のピッチ物質の殆 どは，アニオン性であり，ある程度の安定性を持つ数 $\mu \mathrm{m}$ の微粒子になっている。このピッチは 1 次スティッキー (Primary Sticky) と呼ばれる。しかし一方で，ピッチは 疎水基を持ちかつ粘着性を有するため，抄紙系中の， $\mathrm{pH}$ や電気伝導度，温度などの変動によって，その安定性が失 われ，シェア，壁面への衝突，泡や気液界面での濃縮によ り，数十〜数百 $\mu \mathrm{m}$ に凝集し大きくなる。この凝集物を 2 次スティッキー (Secondary Sticky) と呼ぶ。2次スティ ッキーが製紙工程のピッチトラブルの主要な原因と考えら れている。また，粒径が $150 \mu \mathrm{m}$ 以下のピッチをミクロス ティッキー, $150 \mu \mathrm{m}$ 以上をマクロスティッキーと呼ぶ。

この凝集したピッチが紙料中に抄き込まれ，直接紙中の 欠点となるほか, プレス, ドライヤパートに付着し, 表面 でピッチが徐々に成長した後, 紙に転移されると欠点, 污 れ，穴，断紙を発生させる。

ピッチ障害の発生する箇所は，抄紙工程のほぼ全箇所に 及び，一次循環系，ワイヤー，プレスロール，フェルト， カンバス，カンバスロールである。その中で抄紙工程のド ライヤー以降での発生が多く，生産性への影響も大きい。

\section{5. ピッチ処理の薬品 ${ }^{9) 10}$}

ピッチ処理は，原料工程ではスクリーン，クリーナーを 利用した除塵工程の強化による除去や, 温度, $\mathrm{pH}$ コント ロールによる集塊化防止が実施されている。また抄紙工程 では，2 次スティッキーの発生を抑制するため，様々なピ ッチコントロール剤や凝結剤など薬品が使用されている。 主な薬品の種類と特徴を表 1 に示す。

\section{1 薬品の種類}

\section{(1) 分 散 剂}

ピッチを分散させ，系内に付着するのを防止する。分 散したピッチを白水循環系に滞留させないように処理す る必要がある。

\section{(2) 界面活性剂}

界面活性剂を用いてピッチを分散させる。污れの洗浄 効果も期待できる。分散剤と同様に, 系内に濃縮する可

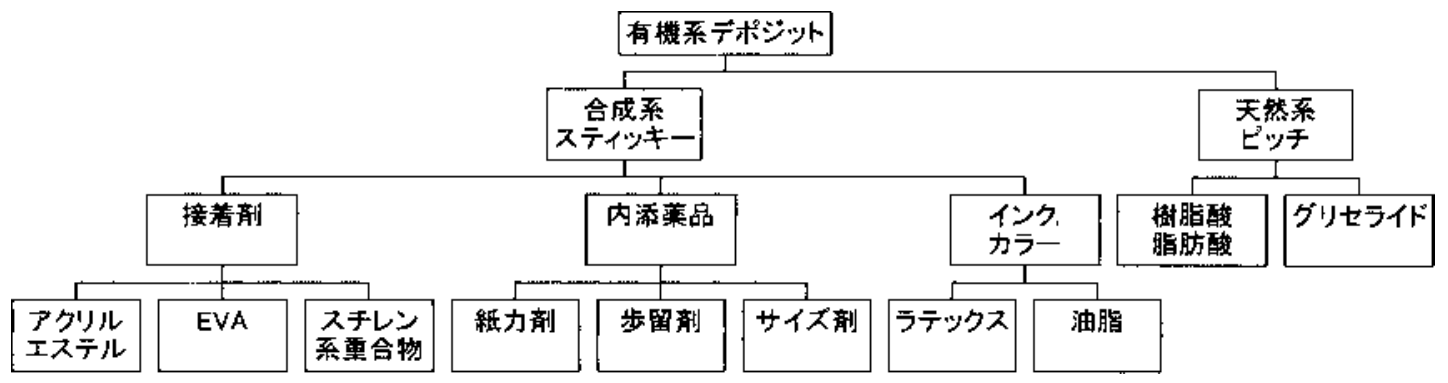

図 2 有機系デポジット（ピッチ）の分類 
表 1 ピッチ処理薬剤の考え方と特徵

\begin{tabular}{|c|c|c|c|}
\hline 考え方 & 薬品の種類 & 特徵 & 問題点 \\
\hline 分散 & $\begin{array}{c}\text { 界面活性剤, } \\
\text { アニオンポリマー }\end{array}$ & ピッチを親水化，添加が容易 & $\begin{array}{c}\text { 系内に濃縮, } \\
\text { サイズへ剂へ悪影響 }\end{array}$ \\
\hline 粘着力低下 & タルク & 安価, 白色度向上 & 用具磨耗, 歩留低 \\
\hline 分解 & 酵素 & 粘着成分の改質 & 効果発現に時間 \\
\hline \multirow[t]{2}{*}{ 紙に定着 } & 硫酸バンド & サイズ刻定着として既に使用 & $\begin{array}{c}\mathrm{pH} \text { によって効果低, } \\
\text { スケール発生 }\end{array}$ \\
\hline & 凝結荗 & ピッチを系外へ排出 & 染料への影響 \\
\hline \multirow[b]{2}{*}{ 可溶化 } & 灯油 & 洗浄力強い & PRTR 該当 \\
\hline & 界面活性荗 & ピッチを乳化 & $\begin{array}{c}\text { 系内に濃縮, } \\
\text { サイズ郕へ悪影響 }\end{array}$ \\
\hline
\end{tabular}

表 2 ピッチの評価方法

\begin{tabular}{|c|c|c|c|c|}
\hline & 対象 & 単位 & 目的 & 問題点 \\
\hline \multicolumn{5}{|l|}{ 定量分析（ピッチの量） } \\
\hline 抽出法 & マクロ・ミクロ & 重量 & 疎水性物質の定量 & パルプ中の物質も抽出 \\
\hline 濁度 & ミクロ & 濁度 & コロイダル物質の量 & 灰分，微細繊維と区別困難 \\
\hline PCD & ミクロ & $\mu e q / L$ & 荷電性コロイダル物質量 & \\
\hline ヘマストメーター & ミクロ & 個数 & 粒子状物質量 & 他の粒子との識別困難 \\
\hline 粒径 & ミクロ & 個数 & コロイダル物質の量 & \\
\hline マクロスティッキー & マクロ & 面積 & 原料, 精製工程の効率 & \\
\hline ミクロスティッキー & ミクロ & 重量 & コロイダル物質の量 & \\
\hline \multicolumn{5}{|l|}{ 定性分析 (ピッチの成分) } \\
\hline FT-IR & 欠点, 付着物 & 定性 & 原因物質の特定 & \\
\hline 熱分解-GC-MS & 欠点, 付着物 & 定性 & 原因物質の特定 & \\
\hline
\end{tabular}

能性があることと，サイズへの影響，発泡の問題がある。 (3) 夕ルク

ピッチを表面に吸着させることで粘着性を低下させる。 安価で, 白色度や灰分率の増加にも寄与できる。歩留が 悪いため，用具の磨耗やタルク自身が系内に付着し污れ の原因になる場合がある。

(4) 酵素

ピッチのエステル結合を分解し粘性を低下させる。醅 素の活性発現のために反応時間が必要になる。

(5) 凝 結 鼡

ピッチはアニオンに帯電しているため, カチオンポリ マーによりピッチを吸着させ，さらにポリマーがパルプ へ定着することで抄紙系外へ排出する。ピッチに対し適 切な荷電，分子量があり，異なったものを用いると効果 を発揮しない。

\section{2 添加方法}

添加方法としては，原料へ添加する内添法と，ピッチの 発生する場所へシャワー水を介して直接添加する外添法が ある。薬品の特徴により，どちらかの方法で使用される。
内添は系全体を処理できる一方で添加量が多くなる場合が ある。外添は污れの付着箇所の近傍に添加するためその場 所を効率的に処理できるが，污れが後段へ移行する可能性 を持つ。

また，薬品の種類によっては定期修理時に系内の洗浄剤 として使用される。

薬品の種類と添加方法および場所は，処理の効果に大き な影響を及ぼすため, ピッチの発生原因や付着状況，原料 事情, 抄造条件, 水回り, マシンフローなどを考慮しなが ら決定する必要がある。

\section{6. ピッチ評価方法 ${ }^{7111}$}

抄紙系内のピッチの状態を把握するためには様々な手段 があり，JIS 化されている方法もある12)。表 2 にピッチの 評価方法の例を示す。これらはいずれも一長一短があり， 満足されるものはないが，目的に応じて使い分けされてい る。凝結剤適用の際などは，濁度や粒径測定などの方法が しばしば用いられている。

また定性分析としては，IR（赤外線吸光光度法）や熱分 


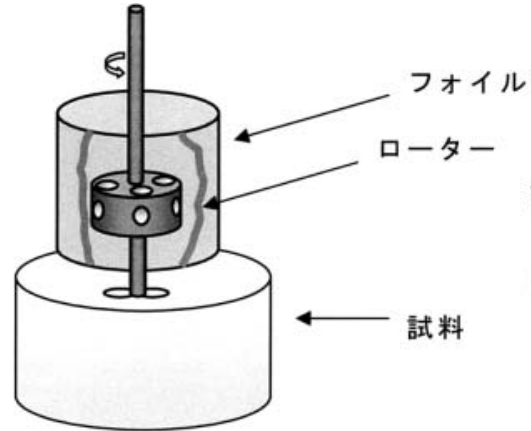

図 3 デポジションローターの概略図

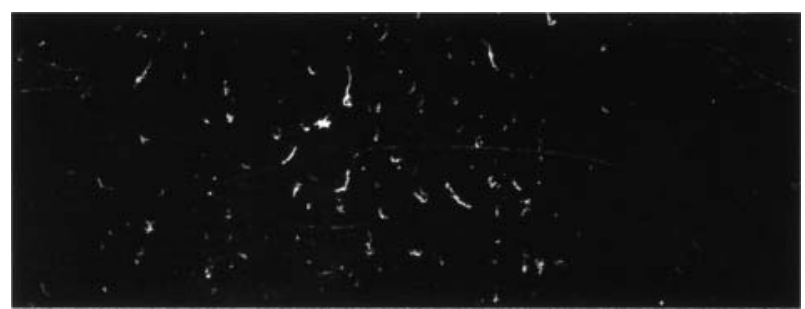

写真 1 デポジションローター試験結果（フォイルの外観 写真)

解 GCMS（ガスクロマトグラフ質量分析法）がよく用いら れている。特に熱分解 GCMS は成分の同定が容易な方法 である。

これらの方法はピッチの存在量を測定する方法であり， そのピッチが実際に系内で付着し悪影響を及ぼすとは限ら ない。そこで弊社は「ピッチの付着や凝集のしやすさ＝污 れポテンシャル」に注目した評価を行なっている。さらに, 各抄紙工程をイメージしていくつかの方法を併用している。

白水循環系をイメージした污れポテンシャルの測定法と して，デポジションローターを用いている。この試験装置 の概略を図 3 に示す。特殊なローターを装着したプロペラ を用いて試料を擋挥することで，ローターの外側に設置し た円筒状のフォイルの表裏に垂直方向と水平方向の流れを 発生させる。粘性を持つピッチであればフォイルに付着す るため，フォイルの表面に付着した物質を観察することで， 污れポテンシャルの評価が可能になる。デポジションロー ターによる污れポテンシャル測定例を写真 1 に示す。フォ イルは黒色に画像処理しており，フォイル上に見られる白 色部が污れ物質が付着した箇所である。污れポテンシャル

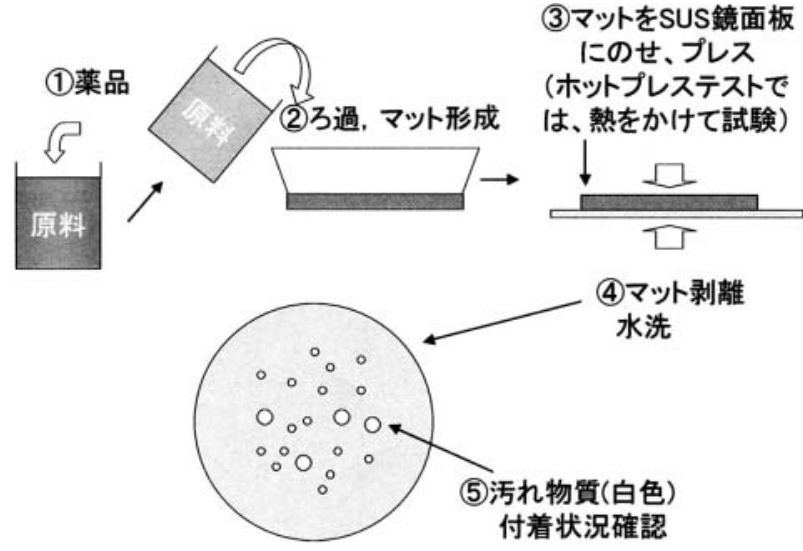

図 4 ホットプレス，プレステストの概略図

が高いと白色部が増加する。

プレスパートを想定した污れポテンシャル測定法として, プレステストを行なっている。本法は, ろ紙上で原料のマ ットを作成し，それをステンレスの鏡面板に乗せ，加圧し たあと剥離し，鏡面板上に残った付着物を画像解析処理す ることで，污れポテンシャルとして測定する。

ドライパートの污れポテンシャルを測定する場合は，プ レステストの加圧の際に圧力と同時にドライヤーに近い条 件で加熱を行う。

図 4 にホットプレス，プレステストの概略図を示す。

\section{7. ピッチ処理事例}

ピッチトラブルを改善するため, 污れポテンシャルを評 価しながら，ピッチコントロール剤を適用した事例を紹介 する。

実施した現場は板紙マシンである。このマシンの中層の 系内やワイヤー上にピッチが付着していた。また，原料に はピッチ分が多く，ピッチの粒径も比較的大きかった。

そこで分散不粘着作用を持つ弊社ピッチコントロール剂 「スパンプラス ${ }^{\circledR} 770 」 の$ 適用を試みた。まず机上にてデポ ジションローター試験を実施した。その結果を写真 2 に示 す。原料の污れポテンシャルが高く，また薬品の添加によ りポテンシャルの低減が可能であることが判った。

この結果より，ピッチコントロール剤で処理できると判 断し，原料系の処理目的で中層のマシンチェストへの内添 と, ワイヤー処理のため中層ワイヤーシャワーへの外添を

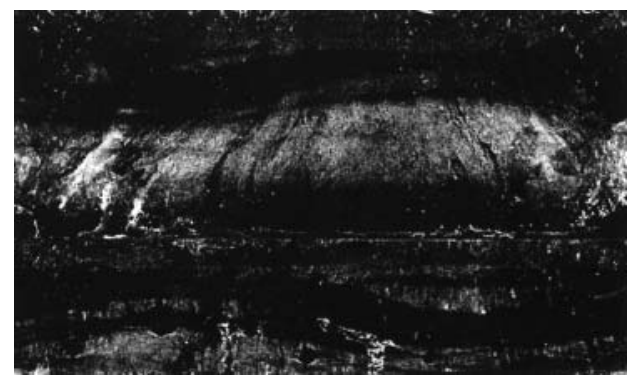

ブランク

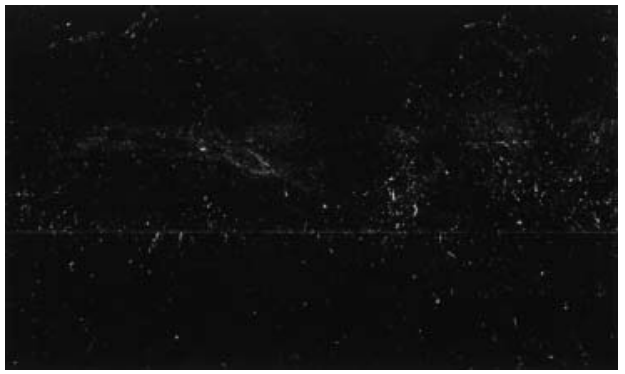

スパンプラス ${ }^{\circledR} 770$

写真 2 デポジションローター試験結果 


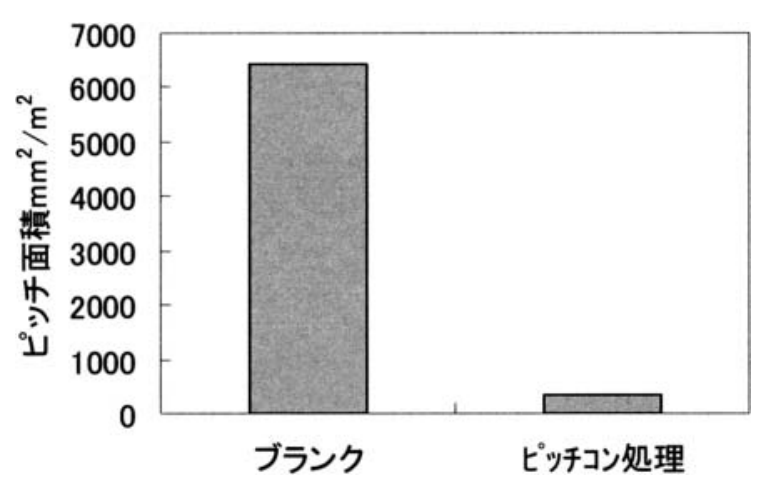

図 5 スパンプラス ${ }^{\circledR} 770$ 適用によるワイヤー上の污れ変 化

行ない, 添加濃度はいずれも $400 \mathrm{ppm}$ とした。添加前後 でのワイヤー上のピッチ污れの変化を図 5 に示す。適用の 結果，ピッチの面積は $98 \%$ 減少した。また欠点数も $1 / 3$ に低減した。

\section{8. おわりに}

かつてピッチ処理といえば，木材に由来する天然系粘着 物が対象であった。しかしながら, 近年の古紙の利用率増 加と品質変化, 抄紙 $\mathrm{pH}$ の中性化, マシン白水のクローズ ド化などにより，ピッチ障害は複雑かつ増加する傾向にな っている。そのため, ピッチトラブルへの対策は万能の方 法がなく, 障害の状況にあわせて色々な角度からアプロー
チをしてゆく必要がある。

弊社としても, 皆様の要求に応えられるよう, 様々な評 価方法や薬品を取り揃えているが，さらにピッチ処理につ いて技術開発をすることで，製紙業界の発展に貢献してい きたい。

\section{References}

1) Chichi Hara : Japanese Journal of Paper Technology 45 (10) 19 (2002)

2) Ministry of Economy, Trade and Industry : Preliminary Report on Paper and Pulp.

3) Masanori Kosuga, et al : Japan Tappi J. 58 (4) 16 (2004)

4) National Diet Library CDNLAD Newsletter 519 (6) 14 (2004)

5) Yasushi Ikeda : Japan Tappi J. 59 (7) 1023 (1997)

6) Katsuaki Nakajima : Japan Tappi J. 53 (9) 1142 (1999)

7) Chen Jiayi : JAPAN TAPPI Annual Meeting, 2002, p 187-198

8) Takeshi Kanazawa : Japan Tappi J. 59 (7) 993 (2005)

9) Peter D. Buikema, et al : Japan Tappi J. 51 (7) 1077 (1997)

10） Motoaki Kimura : Japan Tappi J.60（7） 1005 (2006)

11) T. Krohl, et al : Japan Tappi J. 47 (3) 347 (1993)

12) Recycled pulps-Estimation of Stickies and PlasticsImage analysis method JISP 8231 (2006) 